http://ejournal.upi.edu/index.php/jaz - e-mail: jurnal.zonasi@gmail.com dan jurnal_zonasi@upi.edu doi.org/10.17509/jaz.v3i3.27942

\title{
KAJIAN PERKEMBANGAN SISTEM PETANDA \\ PADA ARSITEKTUR DAN INTERIOR RUANG PUBLIK DI DENPASAR MENUJU DENPASAR KOTA KREATIF
}

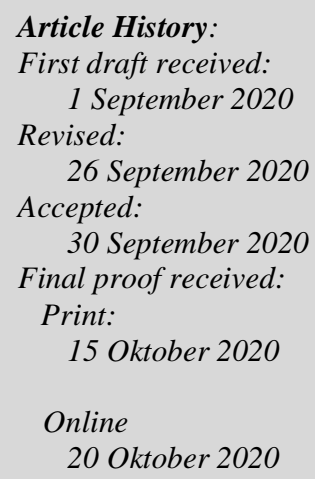

\author{
Ni Nyoman Sri Rahayu ${ }^{1}$ \\ Luh Gde Niti Swari ${ }^{2}$ \\ ${ }^{1,2}$ Institut Desain dan Bisnis Bali, Denpasar, Indonesia \\ J1 Tukad Batanghari No 29, Panjer Denpasar Bali. \\ Email: srirahayu@std-bali.ac.id \\ niti.swari@gmail.com
}

Abstract: The conservation of cultural heritage, especially the identity of traditional architecture in the city of Denpasar, is an effort to strengthen the architectural character of Denpasar. The uniqueness of Denpasar architecture is the peciren bebadungan while the red brick pattern. This also gives an identity to the architectural fasade of Denpasar as a creative city that is appear with local traditions and culture. The signage is one of the important architectural and interior elements and becomes the vocal point. This is due to its function which is visually in front of (building facade), which functions to provide information related to the building. The research method used is descriptive-qualitative method, with the selection of objects using purposive sampling technique. The result of the research is that the signage design does not reflect the strong character of Denpasar architecture. There are two most basic things, which become the main criteria, that was the use of the peciren bebadungan (the form of a red brick pattern arranged) in such as a unique of Denpasar architecture that is different from architecture in another regencies in Bali. The second is the use of Balinese script as a local Balinese identity. These two things are what the authors prioritize in designing, so that creative signage and local wisdom is created.

Keywords: signage, local genius, public space, creative city.

Abstrak: Peneguhan kembali warisan budaya khususnya jatidiri arsitektur tradisional di kota Denpasar merupakan salah satu usaha untuk memperkuat karakter arsitektur Denpasar. Keunikan arsitektur kota Denpasar yang khas (peciren bebadungan berupa pola susun maju mundur material bata merah). Hal ini pula yang memberi identitas bagi wajah arsitektur kota menuju Denpasar sebagai kota kreatif yang selaras dengan tradisi dan budaya local setempat. Sistem petanda atau signage merupakan salah satu elemen arsitektur dan interior yang penting dan menjadi titik focus pengamat dan pengguna bangunan. Hal ini dikarenakan fungsinya yang secara visual berada di muka (fasade bangunan), berfungsi memberikan informasi terkait bangunan. Metode penelitian yang digunakan adalah metode deskriptif-kualitatif, dengan pemilihan objek menggunakan teknik purposive sampling. Hasil penelitian adalah desain signage belum mencerminkan karakter arsitetur Denpasar yang kuat. Terdapat dua hal yang paling mendasar, yang menjadi kriteria utama yakni penggunaan bentuk peciren bebadungan yakni bentuk pola susun maju mundur bata merah yang disusun sedemikian rupa sebagai bentuk khas Arsitektur Denpasar yang unik dan berbeda dengan Kabupaten lainnya di Bali. Yang kedua adalah penggunaan aksara Bali sebagai identitas local Bali. Dua hal ini yang penulis utamakan dalam perancangan, sehingga tercipta signage yang kreatif dan berkearifan local.

Kata Kunci: sistem petanda, kearifan local, ruang public, kota kreatif. 


\section{Pendahuluan}

Mengamati wajah arsitekturnya, bangunan yang ada di sepanjang jalan di Kota Denpasar sebagian besar digunakan fungsi public dan fungsi komersial. Wajah bangunan ini secara umum sangat variatif dan belum mencerminkan wajah arsitektur Bali. Dalam Peraturan Daerah Provinsi Bali No.5 Tahun 2005, tentang persyaratan Arsitektur Bangunan Gedung di Bali, dijelaskan bahwa setiap bangunan harus mencerminkan arsitektur Tradisional Bali. Penggalian kembali akan nilai-nilai dan bentuk arsitektur dan interior nusantara mulai menggeliat beberapa tahun belakangan ini. Kerinduan akan originalitas dan bentuk kearifan local sebagai warisan leluhur yang adiluhung menjadi salah satu alasan. Nilai-nilai originalitas tentu mempunyai ciri khas yang menjadi kekuatan bagi setiap daerah. Di tengah gempuran modernitas, penggalian kembali nilai-nilai tradisional juga menarik guna mengakomodasi kebutuhan desain bagi arsitek dan desainer.

Kajian pustaka tentang arsitektur Denpasar termuat pada (Noorwatha, 2014) dalam tulisannya berjudul Peciren Bebadungan: Studi Identitas Arsitektur Langgam Denpasar, dalam Jurnal Segara Widya, menyatakan bahwa: pemakaian batu bata merah sebagai unsur utama dan modulasi bangunan. Batu bata merah di satu sisi merupakan penanda arsitektur Majapahit, di sisi lain warna merah pada batu bata juga menyiratkan karakter dan watak Denpasar yang berani, tegas, beblakasan, dan to the point. Karakter arsitektur Denpasar juga lebih mementingkan aspek kejelasan struktur pasangan batu bata sebagai elemen dekorasi dengan menerapkan aspek repetisi dan permainan pemasanganya (rhythm).
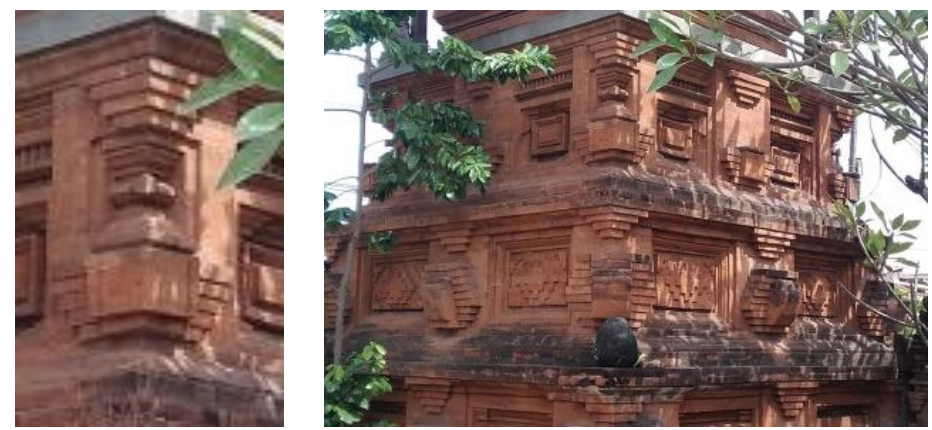

Gambar 1 dan 2. Bentuk peciren bebadungan di Denpasar (Sumber: Dok.pribadi, 2018).

Kajian mengenai arsitektur Denpasar oleh (Yudantini, 2017) dalam tulisannya berjudul "Sejarah dan Perkembangan Kota Denpasar sebagai Kota Budaya" menyatakan bahwa konservasi dapat dicapai melalui dokumentasi mutu, diskusi untuk meningkatkan kesadaran masyarakat tentang nilai-nilai budaya, norma dan estetika, dan dapat ditunjukkan melalui penampilan fisik dari warisan budaya yang menungkinkan orang untuk terlibat, memiliki pengalaman dan menghargai warisan budaya ini.

Tentang signage, (Rahayu, 2018) memaparkan bahwa sebuah karya desain hendaknya mampu adaptif terhadap perkembangan. Peniruan terhadap model lama, bentuk desain baru yang kreatif dan inovatif, tetapi tetap menunjukkan identitas suatu tempat, tanpa harus kehilangan jatidiri. Sehingga dapat dilahirkan karya yang berakar dari budaya sendiri. Lebih lanjut lagi dijelaskan bahwa penguatan jatidiri arsitektur langgam Denpasar dicapai dengan tetap meng-ajeg kan dan mengakomodasi nilai-nilai lokal genius setempat. Menerapkan identitas dan jatidiri arsitektur local setempat merupakan poin utama dari tolok ukur perkembangan arsitektur tradisonal Bali saat ini. Arsitektur langgam Denpasar yang kuat dan teta p dipertahankan, akan menjadi tolak ukur bagi sustainability "ajeg"nya langgam arsitektur Denpasar sebagai identitas dan jatidiri kota Denpasar, ditengah gempuran pluralisme budaya kekinian.

Kota merupakan wahana bagi penduduknya untuk beraktivitas, berinovasi dan berkreasi. (Fitriyana, 2017) dalam tulisannya yang berjudul "Pengembangan Bandung Kota Kreatif Melalui Kolaboratif Komunitas", disebutkan bahwa pentingnya melakukan kolaborasi secara langsung dengan masyarakat, sehingga setiap program/kegiatan yang digagas dapat dirasakan langsung oleh masyarakat. Pemerintah diharapkan melakukan penataan kota yang benar-benar mencerminkan kota kreatif, misalkan dengan memberikan fasilitasi ruang-ruang kreatif dan membangun infrastruktur pendukung lainnya. Wacana Triple helix (pemerintah, akademisi, bisnis) sebaiknya dibarengi dengan menggandeng komunitas kreatif sebagai pihak keempat.

Keunikan Kota Denpasar dibandingkan dengan kota lainnya adalah nuansa budaya dari aktivitas keseharian masyarakat kota; begitupula citra arsitektur kota Denpasar yang khas (peciren bebadungan); kini 
banyak terdapat kreativitas mural di dinding pada beberapa titik di pusat kota. Hal ini pula yang memberi identitas bagi wajah arsitektur kota menuju Denpasar sebagai kota kreatif. Kreatif yang seperti apa, tentu yang selaras dengan tradisi dan budaya local setempat.

Masalah yang dikemukakan: Bagaimana perkembangan signage yang digunakan pada bangunan public di Kota Denpasar? Indicatornya meliputi efektifitas fungsi dan penataannya, informative dan kejelasan, kreatif dan menarik secara visual bagi pengamat dan pengguna bangunan, serta menghadirkan ciri kearifan local sebagai identitas arsitektur Kota Denpasar yang unik dan berbeda dengan Kota lainnya di Bali. Pertanyaan ini akan terjawab pada penelitian yang akan penulis lakukan. Adapun ruang lingkup dalam penelitian adalah lingkup wilayah penelitian yakni bangunan public yang ada di Denpasar seperti bangunan formal seperti kantor pemerintahan, pasar, dan gedung budaya. Begitupula bangunan komersial seperti mall. Tujuan khusus penelitian ini adalah untuk mengetahui perkembangan desain Signage pada bangunan public Di Denpasar dalam mendukung Denpasar sebagai kota kreatif.

Urgensi penelitian ini adalah dengan adanya penerapan desain Signage yang berkearifan local. Dengan dilakukannya penelitian ini diharapkan tercipta desain yang informatif, menarik, dan berkarakter local, sehingga dapat memberi kemudahan bagi pengunjung. Manfaat lain adalah untuk memperkuat identias dan jatidiri karakter arsitektur khas Denpasar, dalam upaya mewujudkan Denpasar sebagai Kota Kreatif.

\section{Metode Penelitian}

Metode penelitian yang digunakan adalah deskriptif-kualitatif. Data dikumpulkan dengan menggunakan metode purposive sampling dengan secara langsung menentukan beberapa bangunan publik dengan kriteria tertentu yang masuk ke dalam bahasan. Data hasil observasi berupa foto-foto sistem petanda pada eksterior dan interior bangunan. Data yang terkumpul kemudian diklasifikasikan berdasarkan fungsi bangunannya yakni bangunan formal dan bangunan komersial. Kemudian disajikan dalam bentuk tabel, sehingga memudahkan pembaca membedakan antara data bangunan satu dan lainnya.

Digunakan metode deskriptif-kualitatif, peneliti mengamati, mengklasifikasikan, dan menginterpretasikan elemen-elemen arsitektural dan interior. Analisis data kualitatif yang digunakan melalui langkah-langkah sebagai berikut: reduksi data, penyajian data dan penarikan kesimpulan. Kategorisasi dan tipologi dapat dibedakan berdasarkan fungsi bangunan, tata letak signage, adanya unsur local (aksara/huruf Bali), warna, penggunaan material bata merah, serta penerapan peciren bebadungan sebagai ciri langgam arsitektur Kota Denpasar. Tahap selanjutnya adalah menyusun kriteria desain signage serta membuat rancangan signage yang berkearifan local, sehingga diharapkan dapat mendukung Denpasar Kota Kreatif.

\section{Hasil dan Pembahasan}

\subsection{Pembahasan}

Disini dianalisis bagaimana bentuk sistem petanda dengan dua tipologi yakni sistem petanda bagi bangunan publik dan bangunan komersial. Sejumlah bangunan formal di Kota Denpasar yang akan dijadikan objek penelitian diantaranya:

1. Gedung Budaya, Dharmanegara Alaya

2. Mall Pelayanan Publik, Graha Sewaka Dharma

3. Museum Bali

4. Kantor Walikota Denpasar

5. Lapangan Puputan Badung

6. Pasar Badung

Sedangkan sejumlah bangunan komersial yang dijadikan objek penelitian, diantaranya:

1. Mall Plaza Renon

2. Ramayana Bali mall

3. Level 21 Mall

4. Bank Mandiri

5. Kantor Garuda Indonesia

6. Ina Bali Heritage Hotel

Arsitektur Tradisional Bali merupakan perwujudan keindahan manusia dan alamnya yang mengeras ke dalam bentuk-bentuk bangunan dengan ragam hias yang dikenakannya (Gelebet, 1985: 331). Ragam hias adalah karya seni rupa yang diambil dari bentuk-bentuk flora, fauna, serta nilai-nilai agama dan kepercayaan yang disarikan ke dalam perwujudan keindahan yang harmonis. Peciren bebadungan merupakan bentuk dari 
pepalihan. Pepalihan merupakan salah satu ragam hias pada Arsitektur Tradisional Bali yang memiliki komposisi garis-garis yang disusun bervariasi dalam suatu pola. Pepalihan ini memiliki corak yang khas dilihat dari bentuk susunan bata merah yang bertingkat-tingkat dengan permainan maju mundur pada pemasangannya. Pepalihan bebadungan ini sekaligus berperan sebagai ornament walaupun dibuat tanpa ukiran. Pepalihan juga dapat digunakan pada bentuk kekarangan seperti karang asti, karang goak, pada bangunan arsitektur tradisional Bali seperti pelinggih, bale kulkul, bale bengong, dan candi bentar. Jenisjenis pepalihan diantaranya : palih wayah, palih madia, palih sancak, palih bacem, dsb (Gelebet, 1986: 420).

Identifikasi pada objek penelitian mengamati sejumlah variable penelitian, diantaranya penerapan beberapa elemen desain sebagai berikut :

1. material lokal (batu bata)

2. warna natural merah bata

3. unsur lokal (aksara/huruf Bali)

4. langgam arsitektur Denpasar (Peciren Bebadungan)

Pembahasan signage ini didasarkan pada kriteria perancangan dalam sistem petanda menurut (Wiryomarmoto, 2002), diantaranya:

1. Penampilan : Petanda yang baik dapat berfungsi sebagai elemen dekoratif dan bisa menyatu dengan elemen fisik di sekitarnya.

2. Keawetan : Menyangkut daya tahan terhadap pengaruh cuaca dan waktu. Pertimbangan adalah tanda pemilihan material. Material yang biasa digunakan adalah besi, perunggu, aluminium, katu, batu, beton, plastic atau fiberglass.

3. Iluminasi : Untuk menarik perhatian terutama di malam hari, perlu dipertimbangkan adanya beberapa cahaya baik internal (dari dalam tanda) maupun eksternal (menggunakan bahan yang bias memantulkan cahaya dari luar).

4. Pesan : Petanda yang akan dirancang sangat tergantung pada pesan yang akan disampaikan. Petanda harus merupakan bagian dari arsitektur disekitarnya dan merupakan kombinasi yang baik antara estetika dan fungsi.

5. Fungsi : Harus disesuaikan dengan kategori berikut : arah (jalan), identifikasi (bangunan, lapangan dan taman), lalu lintas (tanda-tanda lalu lintas dan parkir), informasi (sejarah, lokasi, peristiwa), lambang (spanduk bendera, dinding, elemen, logo).

6. Logo: dapat membantu memberi identitas kota. Dapat dikombinasikan dengan petanda arah, paving, bendera, dan papan informasi. Logo harus mudah dibaca, mudah diaplikasi dalam segala bahan.

7. Legibility : dengan jelas bisa dibaca oleh pengendara tipe dan komposisi, huruf, jarak, penempatan antara tanda.

8. Harmony : sistem petanda harus harmony dengan arsitektur dan bangunan di sekitarnya.

Pada tabel 1 hingga tabel 6 di bawah ini, akan ditampilkan analisis mengenai sistem petanda pada bangunan formal. Sedangkan pada tabel 7 hingga tabel 12, akan ditampilkan analisis mengenai sistem petanda pada bangunan komersial.

Tabel 1. Sistem Petanda pada Bangunan Dharmmanegara Alaya

\begin{tabular}{|c|c|c|c|c|}
\hline Foto sistem petanda & Material & Warna & $\begin{array}{c}\text { Aksara } \\
\text { Bali }\end{array}$ & $\begin{array}{c}\text { Langgam } \\
\text { Peciren }\end{array}$ \\
\hline 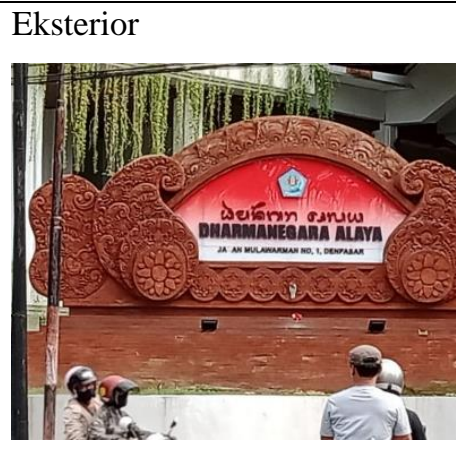 & $\begin{array}{l}\text { Ada } \\
\text { Bata merah }\end{array}$ & $\begin{array}{l}\text { Ada } \\
\text { Merah }\end{array}$ & $\begin{array}{l}\text { Ada } \\
\text { Terlihat } \\
\text { jelas }\end{array}$ & Tidak \\
\hline
\end{tabular}




\begin{tabular}{|l|l|l|c|c|c|}
\hline Foto sistem petanda & Material & Warna & $\begin{array}{c}\text { Aksara } \\
\text { Bali }\end{array}$ & $\begin{array}{c}\text { Langgam } \\
\text { Peciren }\end{array}$ \\
\hline b. Bentuk global mengadopsi bentuk gelung penari Bali.Terdapat pepalihan pada bagian dasar \\
signage. \\
c. Material yang digunakan mayoritas menggunakan bata merah. \\
d. Penyajian keterangan juga menggunakan aksara Bali. \\
e. Penempatan logo mudah dibaca dan diaplikasikan pada sistem petandanya. \\
f. Huruf sudah jelas terbaca oleh pejalan kaki maupun pengendara bermotor. \\
g. Harmoni dengan arsitektur di sekitarnya. \\
h. Penempatannya tidak menggangu visual bangunan. & Tidak & \\
\hline & Tidak & Tidak & Tidak & \\
\hline
\end{tabular}

a. Material yang digunakan adalah besi tempa yang diselesaikan dengan teknik laser cut, finishing black doff.

b. Desain geometris, mudah dibaca oleh pengunjung, dengan back ground kontras.

c. Desain signage sederhana dan tidak berlebihan, dengan mengusung style modern minimalis.

d. Tidak menunjukkan kearifan lokal

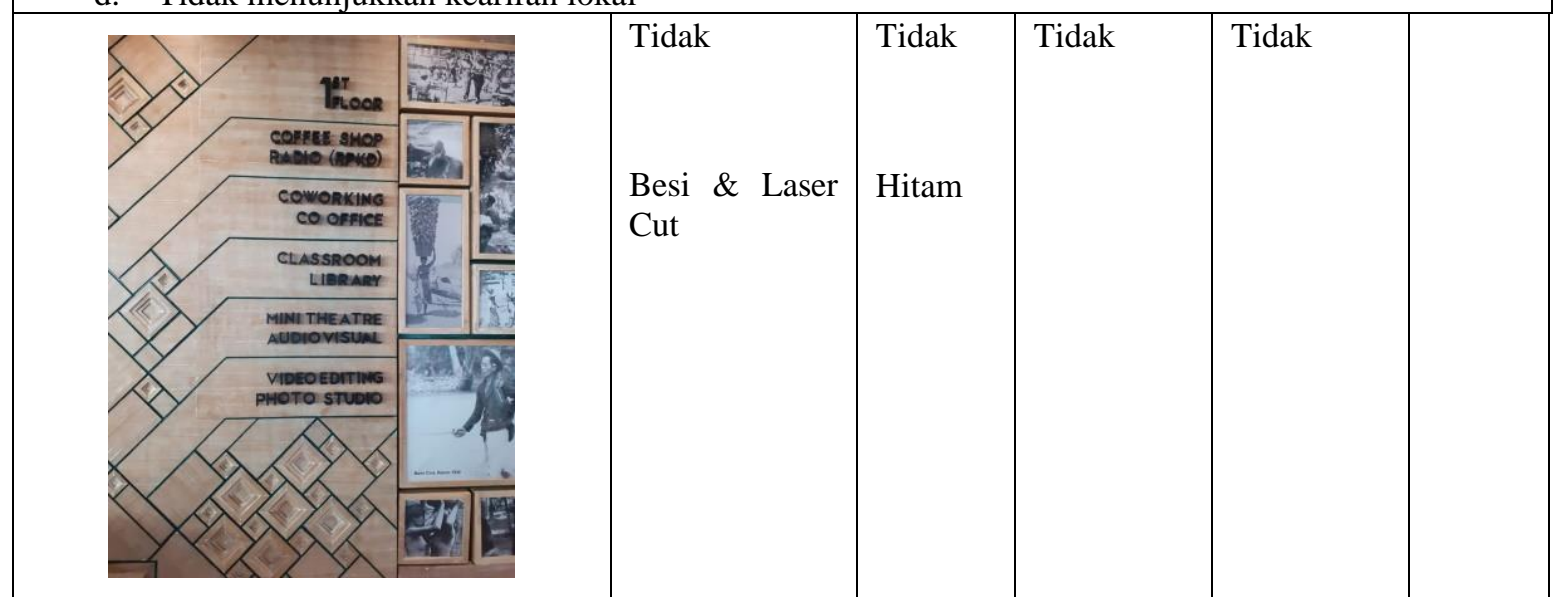

a. Material yang digunakan adalah besi tempa yang diselesaikan dengan teknik laser cut, finishing black doff.

b. Desain signage sederhana dan tidak berlebihan, dengan mengusung style modern minimalis.

c. Tidak menunjukkan kearifan lokal

Sumber: Hasil Observasi, 2020

Petanda disini berfungsi juga sebagai elemen dekoratif. Dengan banyaknya stiliran/ukiran semakin menambah nilai estetika petanda. Dari material, material pada petanda eksterior menggunakan material bata merah sebagai representasi arsitektur Denpasar. Dari segi fungsi, petanda ini sudah berfungsi cukup baik dan informative. Tulisan berdimensi cukup besar sehingga mudah terbaca oleh pengendara. Logo Denpasar tercantum untuk memperkuat identitas bangunan. Mengenai legibility, informasi yang tercantum ada petanda ini sudah cukup jelas mengenai komposisi, huruf, dan jaraknya sehingga mudah terbaca oleh pengendara yang melewatinya. Terdapat harmoni petanda ini dengan bangunan sekitarnya. Harmoni ditunjukkan dari material yang sama (bata merah) pada eksterior bangunan Alaya, dan juga pada eksterior bangunan Graha Sewaka Dharma yang terletak di utara bangunan Alaya. Konstruksi dan strukturnya sudah baik dan aman dalam pemasangan maupun pemeliharaan. Secara umum, arsitektur petanda ini sudah merefleksikan karakter arsitektur Kota Denpasar. Dilihat dari material, dan penggunaan aksara Bali. Logo memperkuat identitas bangunan.

Berbeda dengan material eksteriornya, petanda pada interior bangunan Alaya menerapkan style kontemporer yang lebih kekinian, fungsional dan mudah diterima anak muda. Internasional style yang melekat disini mengedepankan aspek fungsi. Tampilannya cukup memberi nuansa segar dan menarik secara 
visual. Estetika yang tampil dari kesederhanaan bentuk dan material yang digunakan. Ini perlu menjadi perhatian, sebab internasional style justru menjadi boomerang dalam upaya memperkuat identitas suatu elemen arsitektur dalam hal ini petanda. Sehingga perlu menjadi perhatian untuk ke depannya agar desain petanda pada interior dapat lebih memberikan nuansa local yang beridentitas.

Tabel 2. Sistem Petanda pada Bangunan Graha Sewaka Dharma

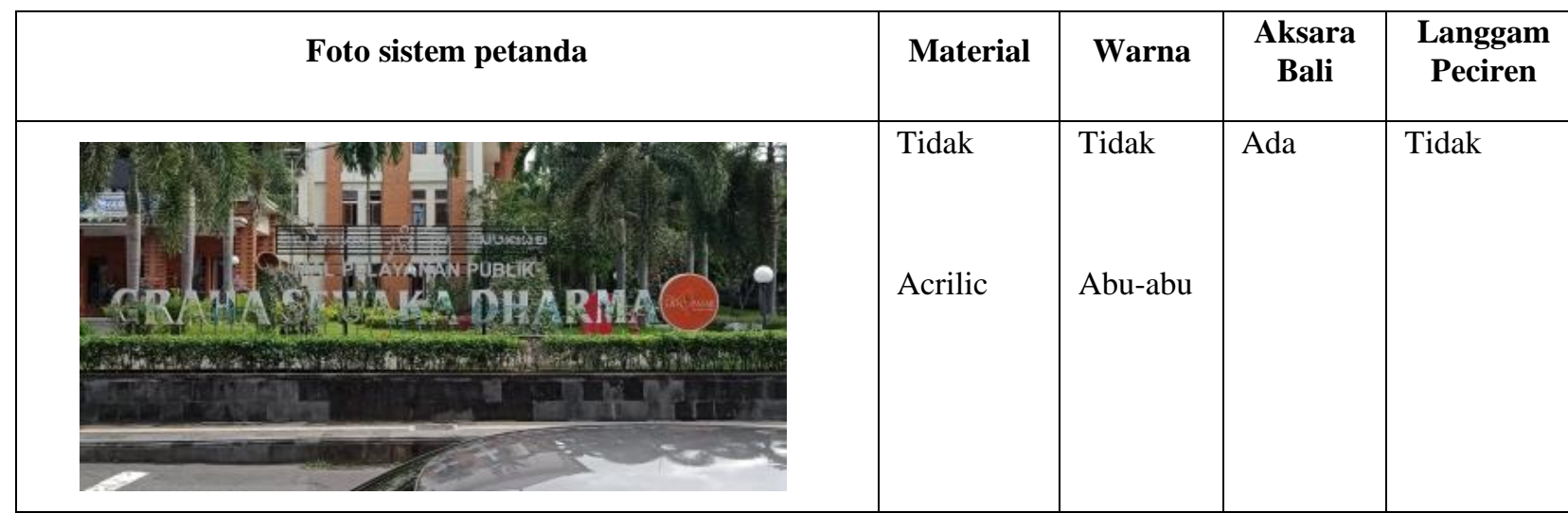

a. Digunakan material acrilic dengan motif tanaman, sehingga memberikan efek blur/kabur/kurang jelas secara visual.

b. Sudah digunakan aksara Bali, walaupun dengan dimensi yang terlalu kecil, sehingga tidak mudah terbaca oleh pengendara.

c. Kurang harmoni dengan arsitektur bangunan utama.

d. Detail logo berupa siluet penari Bali, dengan emblem Kota Denpasar. Namun tulisan "the Heart of Bali" sangat kecil, sehingga kurang terlihat dengan jelas.

e. Desainnya terkesan ramai antara font, latar tulisan, dan latar belakang penempatan font tersebut.

f. Penempatannya tidak mengganggu bangunan maupun penggunanya, tetapi desainnya yg tidak harmonis sehingga terkesan kabur.

g. Nilai estetikanya kurang.
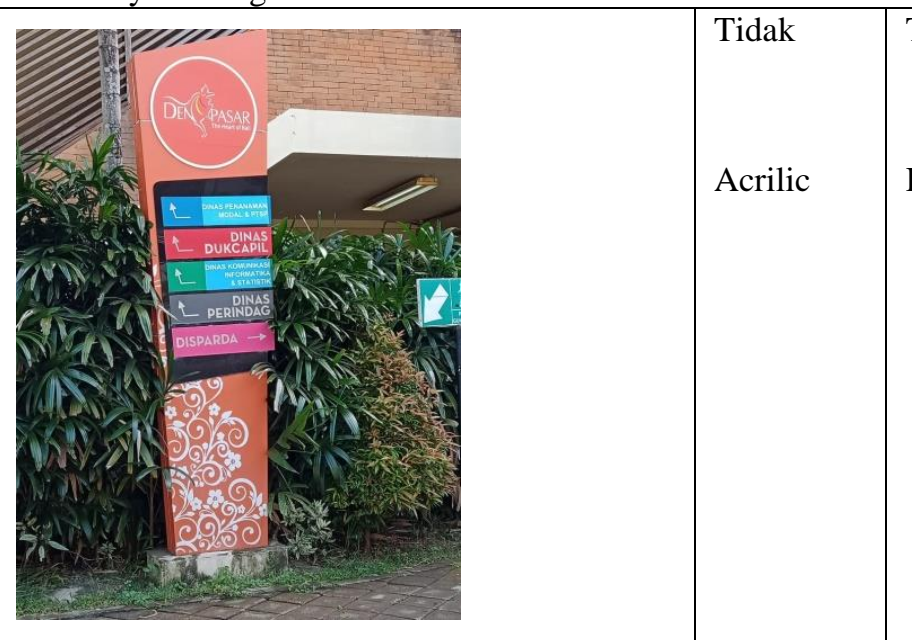

a. Desain kreatif. Sudah ada upaya untuk memasukkan unsur ornamen Bali (pepatran).

b. Material berupa acrilic, mendukung style modern kontemporer.

c. Warna dasar berupa oranye mengadopsi warna bata merah, dengan warna keterangan yang colorful dan eyecathing, sehingga mempermudah pengunjung untuk melihat petunjuk.

d. Digunakan juga logo dan emblem Kota Denpasar.

Sumber: Hasil Observasi, 2020

Petanda pada eksterior bangunan disini berfungsi juga sebagai elemen dekoratif. Dari material digunakan acrylic, dengan tambahan penyajian berupa aksara Bali. Berupaya menampilkan identitas local. Dari segi fungsi, petanda ini sudah berfungsi baik dan informative. Tulisan berdimensi cukup besar sehingga mudah terbaca oleh pengendara. Namun pemilihan warna acrylic dengan motif tumbuhan yang sama dgn latar di bawahnya, justru mengaburkan pandangan sehingga tidak mudah terbaca oleh pengendara yang sedang melintas. Logo tercantum, sehingga memperkuat identitas bangunan ini. 
Mengenai legibility, informasi yang tercantum ada petanda ini sudah cukup jelas mengenai komposisi, huruf, dan jaraknya. Harmoni belum ditunjukkan pada petanda ini dengan bangunan sekitarnya. Pemilihan material berupa acrylic dengan style modern membuatnya kontras dengan bangunan sekitar. Aspek fungsional, dan trend menjadi pertimbangan utama. Kontras disini tidak sepenuhnya buruk, hanya ini memberi kesan yang kurang harmonis dengan eksterior bangunan yang secara umum menggunakan bata merah. Begitupula pada bangunan Alaya yang terletak di sisi selatannya. Konstruksi dan strukturnya sudah baik dan aman dalama pemasangan maupun pemeliharaan. Secara umum, petanda eksterior belum merefleksikan karakter arsitektur Kota Denpasar dilihat dari material.

Tabel 3. Sistem Petanda pada Museum Bali

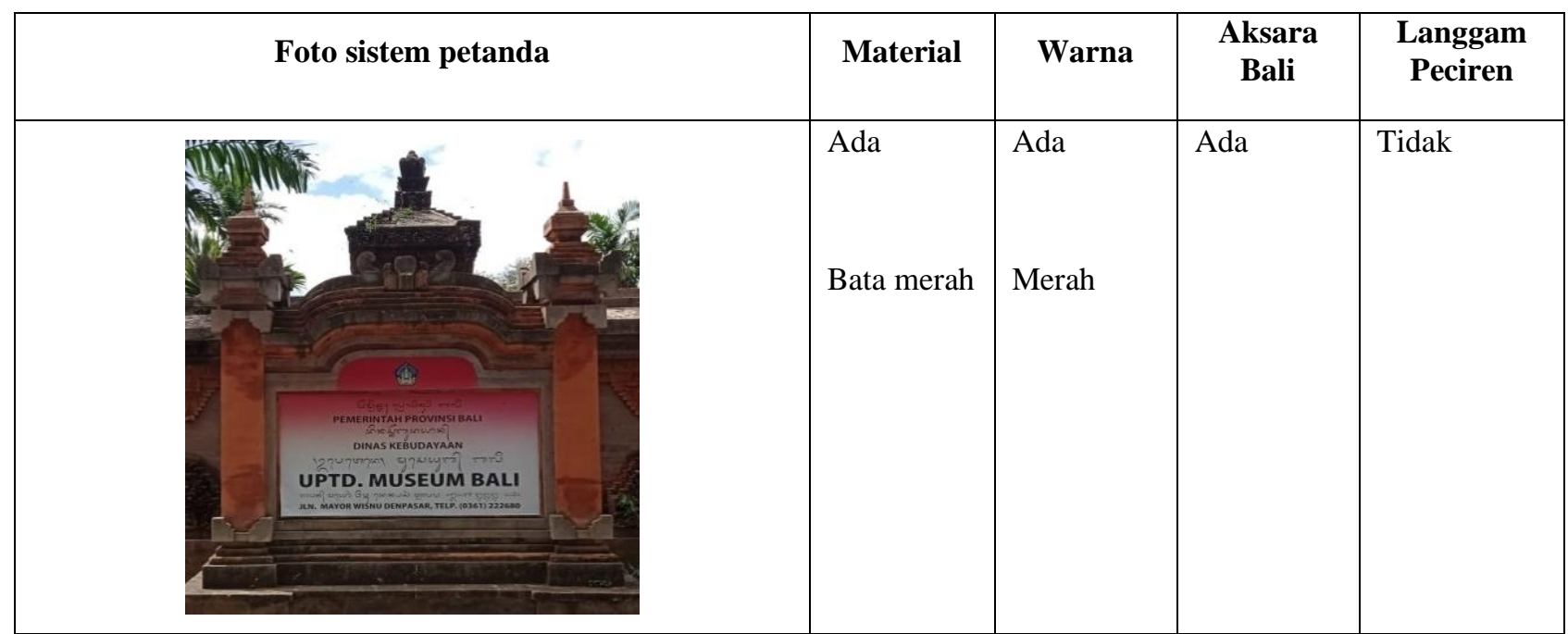

a. Model signage trend pada tahun 1990an, dengan material bata merah dan paras abu-abu.

b. Background tulisan menggunakan gradasi merah dan putih.

c. Proporsi huruf pas.

d. Digunakan aksara Bali

e. Mengadopsi bentuk pilar eksterior (paduraksa) pada bangunan tradisional Bali.

f. Penempatannya tidak menggangu bangunan sekitar.

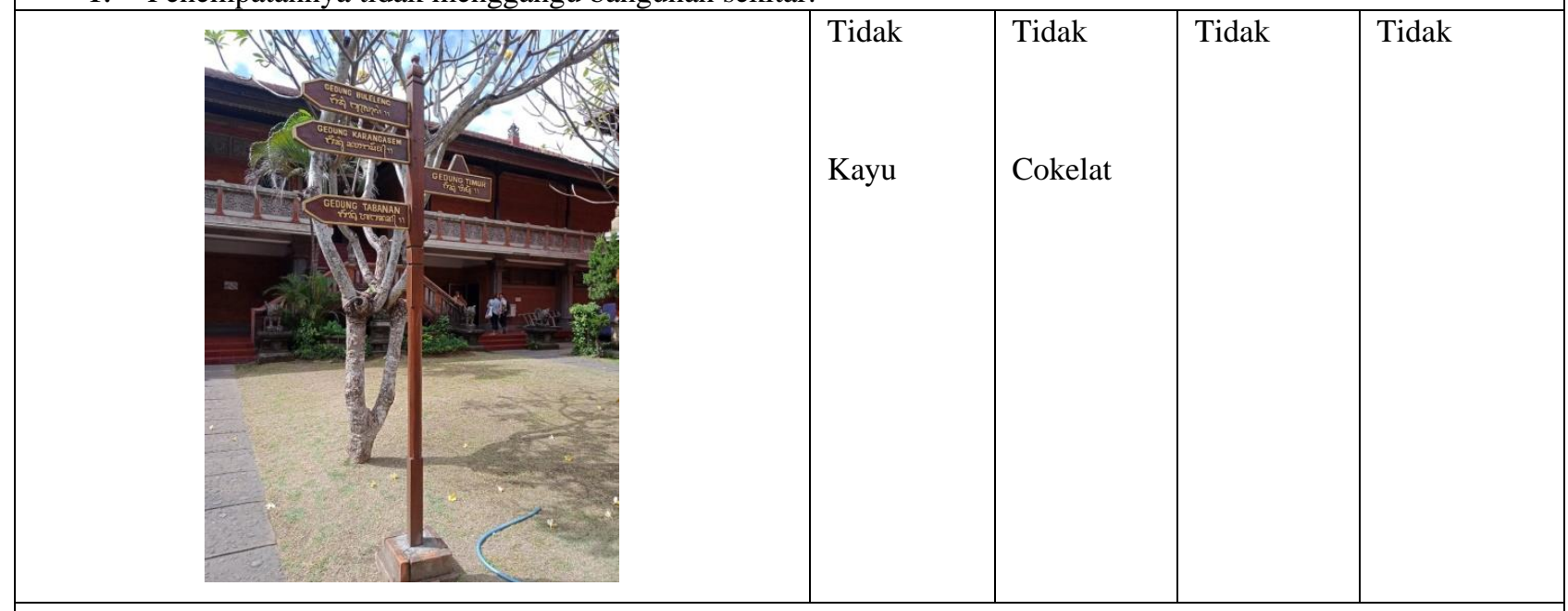

a. Bentuk sederhana mengadopsi detail pilar interior (sesaka) pada arsitektur tradisional Bali.

b. Material digunakan kayu.

c. Digunakan aksara Bali.

d. Warna Gold, sehingga mudah dilihat

e. Cukup informatif. 
Tabel 4

Sistem Petanda pada Kantor Walikota Denpasar

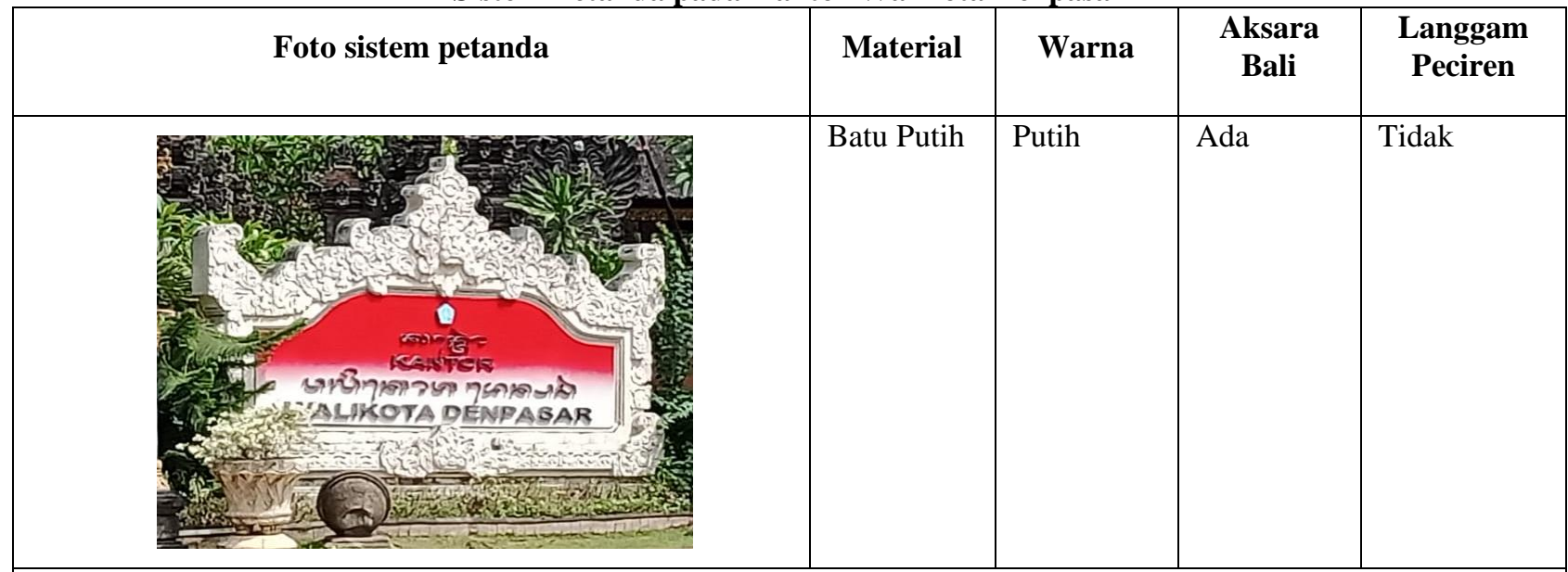

a. Material digunakan batu paras putih.

b. Desain menggunakan bentuk karang boma.

c. Background tulisan merupakan warna gradasi merah dan putih sebagai warna bendera Bangsa Indonesia.

d. Digunakan aksara Bali

e. Proporsi tulisan sudah baik, dan mudah terbaca oleg pengendara.

f. Logo dibuat dengan dimensi cukup kecil.

g. Desain terkesan menonjol secara visual dan kontras dibandingkan dengan bangunan sekitar.

Sumber: Hasil Observasi, 2020

Tabel 5. Sistem Petanda pada lapangan Puputan Badung

\begin{tabular}{|c|c|c|c|c|}
\hline Foto sistem petanda & Material & Warna & $\begin{array}{c}\text { Aksara } \\
\text { Bali }\end{array}$ & $\begin{array}{c}\text { Langgam } \\
\text { Peciren }\end{array}$ \\
\hline 6 & $\begin{array}{l}\text { Ada } \\
\text { Bata } \\
\text { merah }\end{array}$ & $\begin{array}{l}\text { Ada } \\
\text { Merah }\end{array}$ & Ada & Tidak \\
\hline $\begin{array}{l}\text { a. Material digunakan bata merah } \\
\text { b. Desain menggunakan bentuk } k c \\
\text { energi negatif. Dengan tujuan ur } \\
\text { c. Bentuk global mengadopsi bent } \\
\text { d. Desainnya terkesan monoton. }\end{array}$ & $\begin{array}{l}\text { nerupakan si } \\
\text { sifat-sifat } \mathrm{rc} \\
\text { u masuk pad }\end{array}$ & $\begin{array}{l}\text { bol raksasa } \\
\text { sasa. } \\
\text { puri dan pu }\end{array}$ & rmakna sel & ai penetralisis \\
\hline
\end{tabular}

Sumber: Hasil Observasi, 2020

Petanda disini berfungsi juga sebagai elemen dekoratif. Dari material mata merah, tampak menyatu dengan material patung Catur Muka yang juga menggunakan material bata merah. Material pada tulisan berupa batu granit hitam merupakan material yang awet dan tahan lama. Pencahayaan di malam hari, menggunakan lampu spotlight terletak di bagian bawah kanan dan kiri signage.

Dari segi fungsi, petanda ini sudah berfungsi baik dan informative. Tulisan berdimensi cukup besar sehingga mudah terbaca oleh pengendara. Logo tidak tercantum, karena memang tidak ada logo khusus untuk Lapangan ini. Mengenai legibility, informasi yang tercantum ada petanda ini sudah cukup jelas mengenai komposisi, huruf, dan jaraknya sehingga mudah terbaca oleh pengendara yang melewatinya. 
Harmoni petanda ini dengan bangunan sekitarnya. Petanda ini terletak di pojok lapangan, bersebelahan dengan traffic light, dan juga bersebelahan dengan patung Catur Muka yang berfungsi juga sebagai ikon Kota Denpasar. Harmoni ditunjukkan dari material yang sama yakni bata merah pada petanda dan juga pada patung Catur Muka. Konstruksi dan strukturnya sudah baik dan aman dalama pemasangan maupun pemeliharaan. Secara umum, arsitektur petanda ini sudah merefleksikan karakter arsitektur Kota Denpasar. Dilihat dari material, dan penggunaan aksara Bali.

Tabel 6. Sistem Petanda pada Pasar Badung

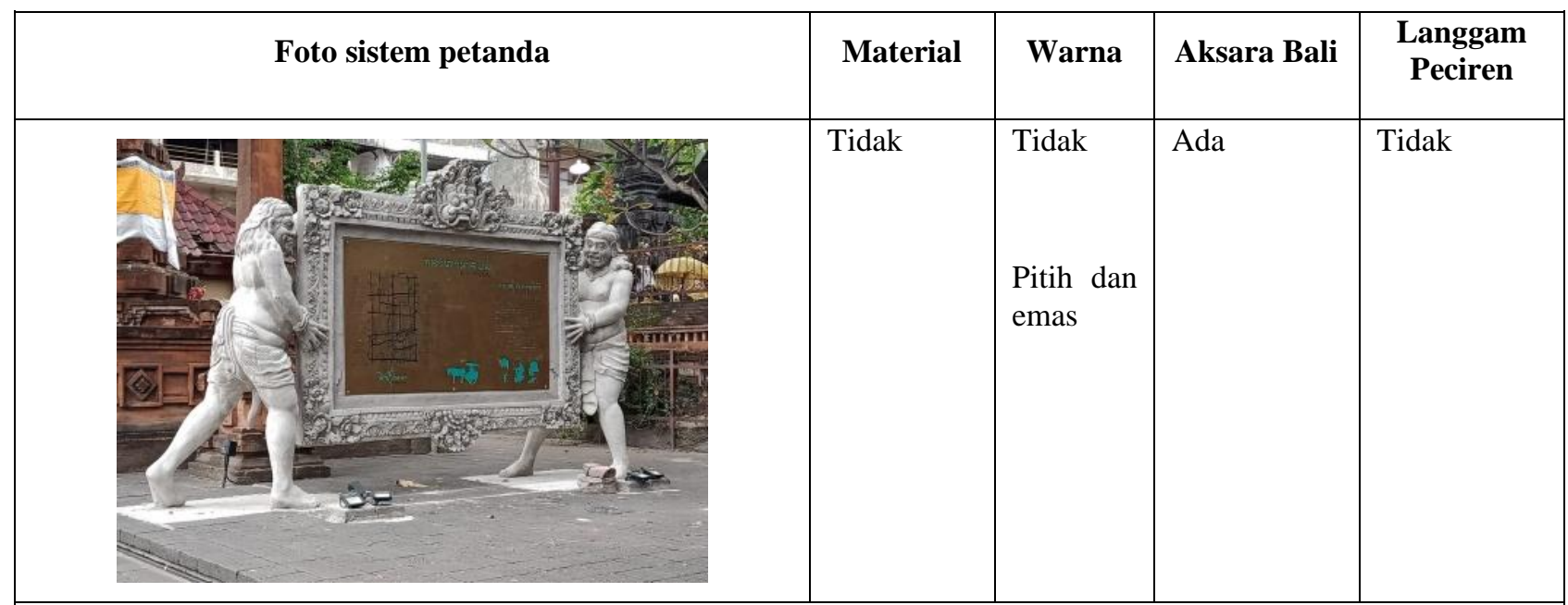

a. Material yang digunakan berupa batu paras putih yang dipahat dan diukir, digunakan bentuk raksasa yang memegang pigura.

b. Pigura menggunakan material kuningan. Bercerita tentang peta koridor jalan Gajah Mada dan sekitarnya.

c. Untuk bisa membaca keterangan pada peta tersebut, pengunjung harus melihatnya dari jarak dekat.

d. Digunakan aksara Bali.

e. Material yang kontras dengan sekitar membuatnya menjadi point of interest.

Sumber: Hasil Observasi, 2020

Tabel 7. Sistem Petanda pada Mall Plaza Renon

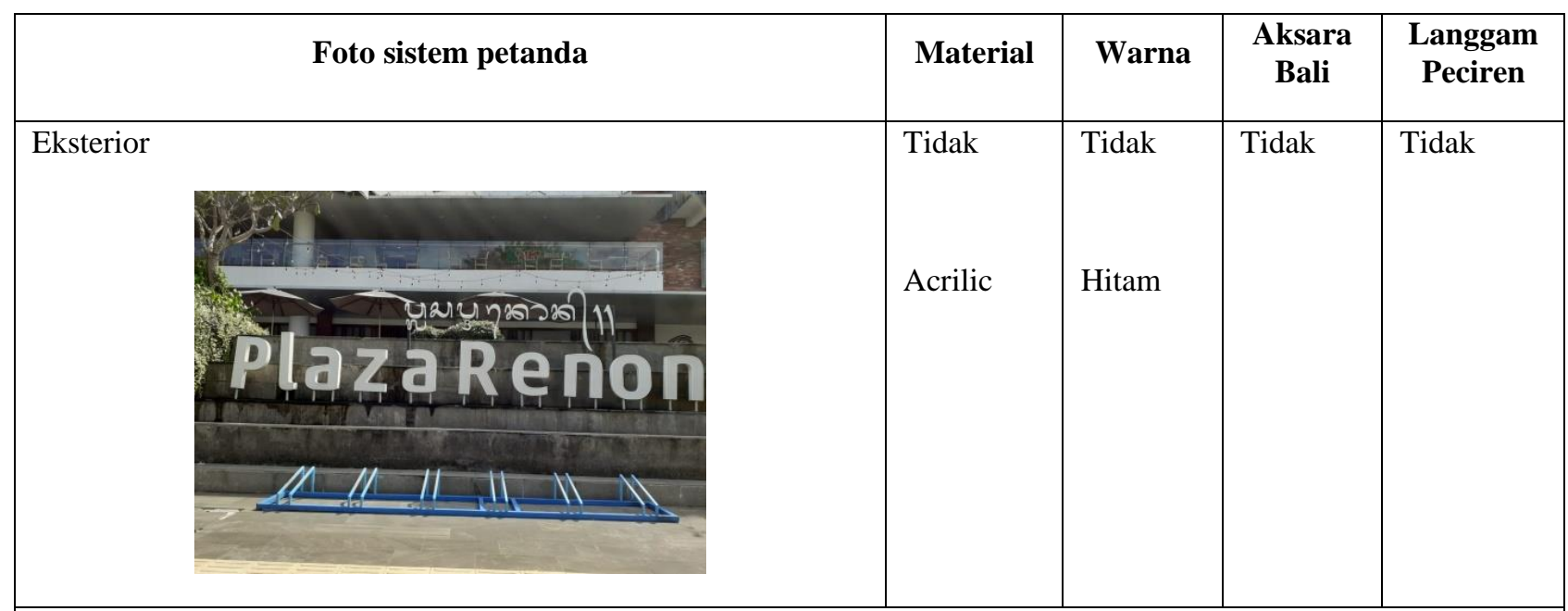

a. Digunakan material acrylic dengan finishing warna putih sehingga memberi kesan cukup jelas, karena berbeda dengan background.

b. Digunakan aksara Bali.

c. Sangat jelas terlihat bagi pengendara bermotor dan Pejalan kaki.

d. Penempatan penanda tidak mengganggu gedung dan lingkungannya, jelas, mudah di capai karena berada di area yg dilalui banyak orang.

e. Tulisannya sudah jelas 


\begin{tabular}{|c|c|c|c|c|}
\hline Foto sistem petanda & Material & Warna & $\begin{array}{c}\text { Aksara } \\
\text { Bali }\end{array}$ & $\begin{array}{c}\text { Langgam } \\
\text { Peciren }\end{array}$ \\
\hline $\begin{aligned} \text { DISOUTH ENTRANCE/C } \\
\vdots \\
\vdots \\
\vdots\end{aligned}$ & $\begin{array}{l}\text { Tidak } \\
\text { Acrilic }\end{array}$ & Tidak & Tidak & Tidak \\
\hline $\begin{array}{l}\text { a. Tulisan cukup jelas } \\
\text { b. Mengusung style minimalis } \\
\text { c. Hanya digunakan bahasa Inggris saja. Tidak digunakan } \\
\text { bhs Indonesia. } \\
\text { d. Menggunakan material akrilik dengan finishing warna } \\
\text { biru doft dengan tulisan berwarna putih. } \\
\text { e. Desain simple dan minimalis. } \\
\text { f. Penempatan di area yg mudah di temukan dan di } \\
\text { jangkau. } \\
\text { g. Terbaca dengan jelas. } \\
\text { h. Desainnya simple dan minimalis. }\end{array}$ & & & & \\
\hline 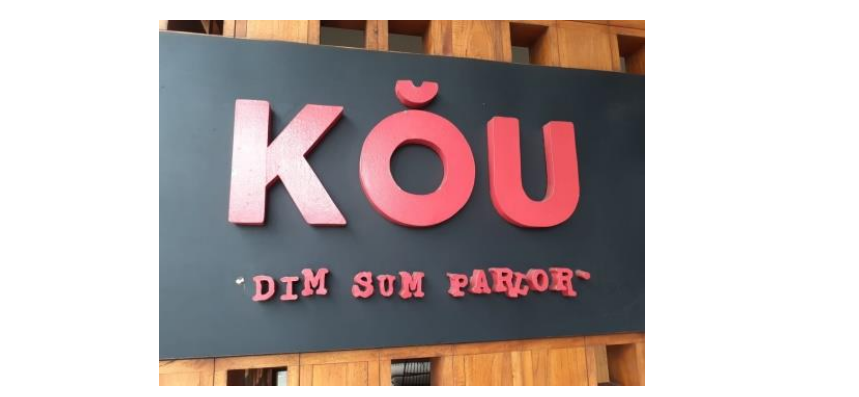 & $\begin{array}{l}\text { Tidak } \\
\text { Acrilic }\end{array}$ & $\begin{array}{l}\text { Tidak } \\
\text { Hitam }\end{array}$ & Tidak & Tidak \\
\hline \multicolumn{5}{|l|}{$\begin{array}{l}\text { a. Desainnya menggunakan material besi tempa dengan finishing } \\
\text { b. Mudah dijangkau,jelas dan informatif. } \\
\text { c. Dengan tulisan berwarna merah dengan material besi tempa. } \\
\text { d. Serasi dengan lingkungan sekitar dan mudah ditemukan. } \\
\text { e. Tidak menggunakan aksara Bali. }\end{array}$} \\
\hline
\end{tabular}

Sumber: Hasil Observasi, 2020

Tabel 8. Sistem Petanda pada Ramayana Bali Mall

\begin{tabular}{|l|l|l|l|l|}
\hline Foto sistem petanda & Material & Warna & $\begin{array}{c}\text { Aksara } \\
\text { Bali }\end{array}$ & $\begin{array}{c}\text { Langgam } \\
\text { Peciren }\end{array}$ \\
\hline
\end{tabular}




\begin{tabular}{|c|c|c|c|c|c|}
\hline \multicolumn{6}{|c|}{$\begin{array}{r}\text { Rahayu; Swari, Kajian Perkembangan Sistem Petanda pada Arsitektur dan Interior Ruang Publik } \\
\text { Volume } 3 \text { - Nomor } 3 \text { - Oktober } 2020\end{array}$} \\
\hline & Foto sistem petanda & Material & Warna & Aksara & $\begin{array}{c}\text { Langgam } \\
\text { Peciren }\end{array}$ \\
\hline & $\begin{array}{l}\text { putih membuat signage ini sebagai point of interest. } \\
\text { Sangat jelas, terbaca, dan mudah dijumpai. } \\
\text { Serasi dengan lingkungannya. } \\
\text { Material nya menggunakan akrilik dengan warna } \\
\text { background merah dan tulisan putih. } \\
\text { Tidak menggunakan aksara Bali. }\end{array}$ & & & & \\
\hline
\end{tabular}

Tabel 9. Sistem Petanda pada Level 21 Mall

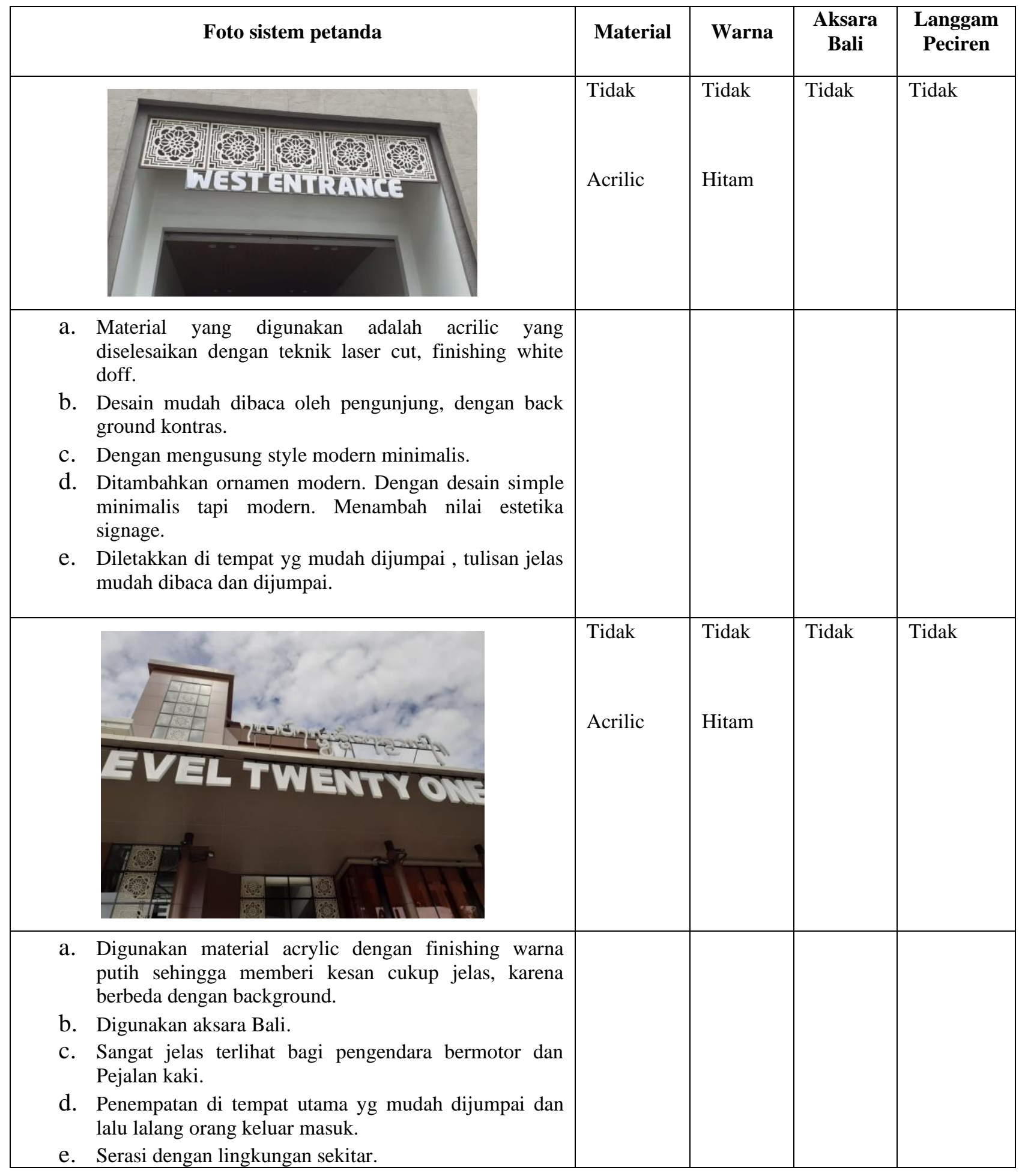




\begin{tabular}{|l|l|l|l|l|l|}
\hline \multicolumn{3}{|c|}{ Rahayu; Swari, Kajian Perkembangan Sistem Petanda pada Arsitektur dan Interior Ruang Publik } \\
Volume 3 - Nomor 3 - Oktober 2020
\end{tabular}

Sumber: Hasil Observasi, 2020

Tabel 10. Sistem Petanda pada Bank Mandiri, JI Veteran Denpasar

\begin{tabular}{|l|l|l|l|l|}
\hline Foto sistem petanda & Material & Warna & $\begin{array}{c}\text { Aksara } \\
\text { Bali }\end{array}$ & $\begin{array}{c}\text { Langgam } \\
\text { Peciren }\end{array}$ \\
\hline & Ada & Ada & Ada & Ada \\
\hline & $\begin{array}{l}\text { Bata } \\
\text { merah }\end{array}$ & Merah & & \\
\hline
\end{tabular}

a. Menggunakan material batu bata merah dengan menggunakan ornamen Bali.

b. Dengan background warna hitam dan tulisan berwarna gold. 

c. Penempatan di tempat yg mudah dijangkau dan dilalui.
d. Terdapat aksara bali.
e. Tulisan jelas dan mudah terbaca.

Tabel 11. Sistem Petanda pada Inna Bali Heritage Hotel

\begin{tabular}{|l|l|l|l|l|}
\hline \multicolumn{1}{|c|}{ Foto sistem petanda } & Material & Warna & $\begin{array}{c}\text { Aksara } \\
\text { Bali }\end{array}$ & $\begin{array}{c}\text { Langgam } \\
\text { Peciren }\end{array}$ \\
\hline & Acrilic & Tidak & Tidak & Tidak \\
\hline INNA BALI HERITAGE & & & & \\
\hline
\end{tabular}

a. Ditempatkan di area yg mudah dilalui orang. Menggunakan material akrilik dengan ditambahkan lampu. dengan background menggunakan warna putih dengan tulisan warna merah .

b. Ditambahkan ornamen sulur di atasnya dari material besi tempa.

c. Tidak terdapat aksara bali.

d. Tulisan terbaca jelas.

e. Desainnya simple dan modern

\section{Tabel 12. Sistem Petanda}

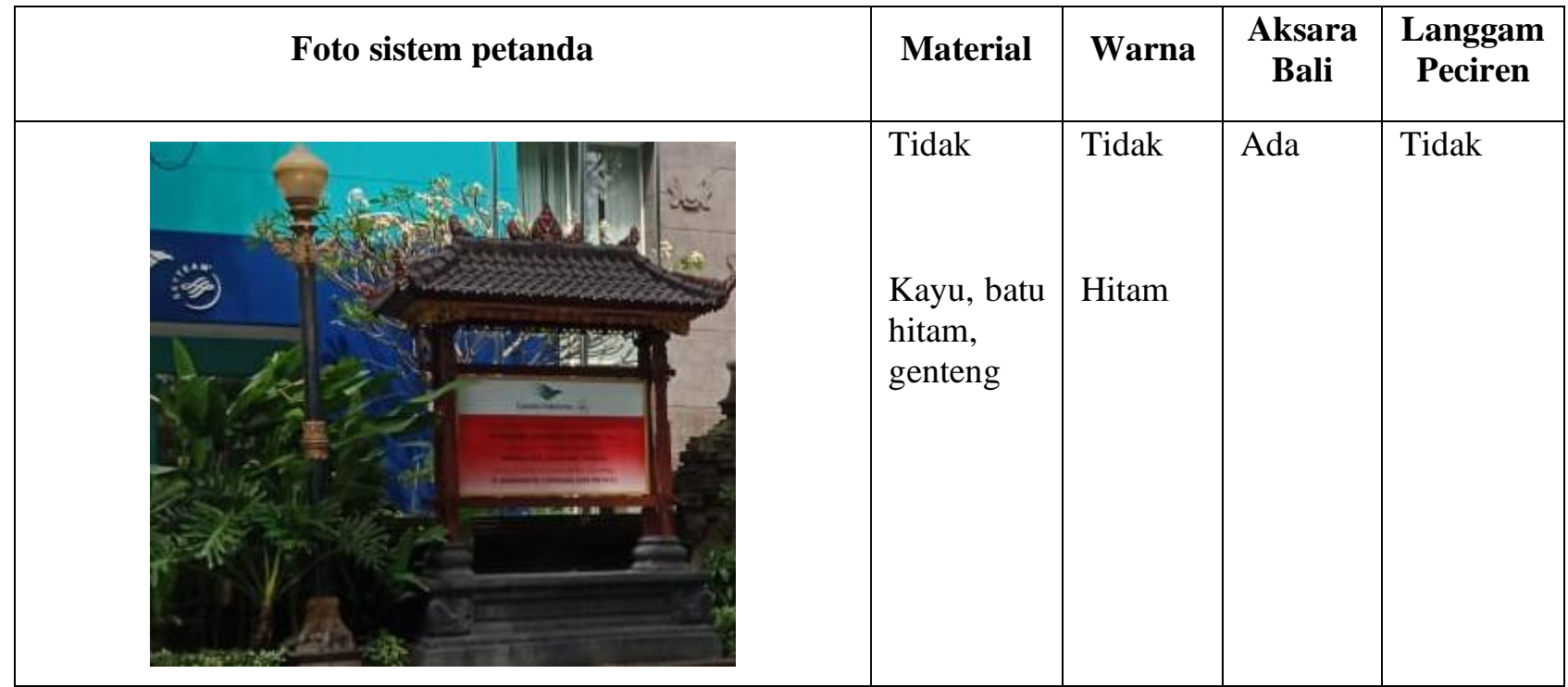

a. Material kayu sebagai pilar penyangga signage.

b. Terdapat aksara Bali

c. Terdapat Logo perusahaan

d. Tulisan berdimensi standar, namun kurang terbaca jelas bagi pengendara.

e. Menampilkan karakter arsitektur tradisional Bali, namun belum menampilkan karakter arsitetur tradisional Denpasar.

f. Kontras dengan bangunan di belakangnya yang berstyle modern. 
Berdasarkan hasil observasi, ditemukan beberapa kesamaan signage pada eksterior, yakni: penggunaan latar merah putih, adanya penggunaan aksara Bali. Dari semua sistem petanda yang diteliti, hanya satu yang menampilkan bentuk peciren bebadungan, yakni pada eksterior Bank Mandiri. Bentuk peciren bebadungan berupa pola susun maju mundur bata merah, dibuat dalam desain yang kontemporer dan kekinian, Nampak pada bagian badan signage.

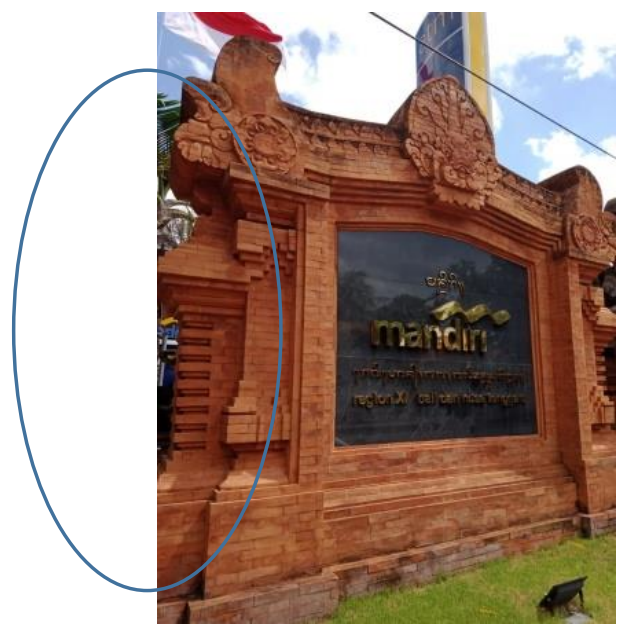

Gambar 3. Bentuk modifikasi peciren bebadungan Sumber: Dok.pribadi, 2018

Pada bangunan Alaya Dharmanegara, sistem petanda pada eksteriornya merupakan bentuk kontemporer dari ornament tradisional Bali. Juga motif mote-motean, dan gelung (hiasan kepala) penari Bali. Penggunaan latar merah dan putih merupakan identitas bendera bangsa Indonesia, cukup mendominasi pada signage yang diteliti. Sistem petanda pada interior bangunan, dari semua objek penelitian, diterapkan style modern dan belum mencirikan identitas arsitektur Denpasar. Material kekinian, dan trend terbaru menjadi pilihan perancang. Namun hal ini justru membuatnya kehilangan identitas.

Mengenai pemilihan material terbarukan yakni material acrylic, dan metal (besi tempa) adalah satu keniscayaan. Pertimbangan material yang fungsional, efisien dan mudah pemasangannya menjadi hal yang utama dalam penggunaan material ini. Material ini mudah dikerjakan, cepat, harga relative murah, dan mudah dipindah-pindah (moveable) dan mudah dibersihkan (maintenance). Juga dapat dipadukan dengan warna yang colorfull dari pemasangan LED misalnya. Pertimbangan lain adalah trend kekinian yang dengan sangat mudah lekat di hati generasi muda. Kebaruan dan inovasi juga menjadi hal yang menarik di mata generasi tua. Estetika modern yang tampil memberi nuansa fresh, up to date, dan menarik. Style kontemporer bagi generasi milenial adalah sudah dianggap lumrah. Ini menjadi perhatian. Diperlukan pemahaman dan contoh real yang mudah diterima generasi muda agar tetap ingat jatidirinya, salah satunya dengan bentukan arsitektur.

Ke depannya hal ini perlu diperhatikan dimana pemlilihan material yang tepat, untuk fungsi bangunan yang tepat tentu akan lebih baik. Desain yang tidak sepenuhnya kontemporer dan modern, namun lebih percaya diri dengan kearifan local yang disajikan dengan menarik dan kekinian sehingga membangkitkan kecintaan generasi muda terhadap budaya local sendiri.

Disini penulis garus bawahi terdapat dua hal yang diperhatikan dalam perancanga signage ini, yakni penerapan bentuk peciren bebadungan baik secara utuh maupun bentuk yang ditransformasikan ke bentuk baru. Peciren bebadungan yakni pola susun maju mundur bata merah sebagai bentuk khas Arsitektur Denpasar yang membedakannya dengan Kabupaten lainnya di Bali. Bentuk ini tidak menggunakan ukiran, sehingga estetika muncul dari permainan dimensi dan tata letak bata merah. Yang kedua adalah pengguaan aksara Bali sebagai identitas local Bali. Dua hal ini yang penulis utamakan dalam perancangan, sehingga tercipta signage yang kreatif dan berkearifan lokal.

\subsection{Kriteria Rancangan Signage}

Kriteria rancangan signage disini adalah memperhatikan prinsip pemasangan dan fungsi sesuai standar, seperti : 
1. Memiliki konstruksi yang aman secara visual, aman dalam pelaksanaan pemasangannya, dan aman dalam operasionalnya.

2. Dibuat dengan format yang sama dalam kategori bentuk, ukuran, struktur, dan posisi atau tempat pemasangan.

3. Menarik secara visual

4. harmonis dengan bangunan arsitektur di sekitar lokasi.

5. merefleksikan karakter kawasan Denpasar Kota Kreatif

6. Jarak dan ukuran harus memadahi dan diatur sedemikian rupa agar menjamin jarak penglihatan

Untuk memperkuat karakter Arsitektur Denpasar, penulis dapat rangkum beberapa kriteria yang dapat dijadikan acuan bagi desainer dalam merancang signage eksterior dan interior bangunan, diantaranya:

Pada signage eksterior bangunan formal, terdapat beberapa kriteria diantaranya:diantaranya:

a. Menampilkan karakter arsitektur tradisional Bali dengan menggunakan material bata merah dan warna natural dari bata merah.

b. Menampilkan aksara bali dari nama bangunan.

c. Menerapkan bentuk peciren bebadungan sebagai karakter arsitektur Denpasar.

d. Ditampilkan secara sudah informative dan menarik.

Pada signage interior bangunan formal, terdapat beberapa kriteria diantaranya:

a.Menggunakan material terbaru yang fungsional dan efisien.

b. Warna dominan menggunakan warna merah bata.

c.Tidak diharuskan, namun jika memungkinkan dapat digunakan aksara Bali

d. Menampilkan karakter peciren bebadungan pada frame (bingkai).

Kriteria bagi signage eksterior bangunan komersial, diantaranya:

a. Dapat menggunakan material terbaru seperti acrylic, metal, dan sebagainya.

b. Menggunakan warna yang mendekati warna merah bata.

c. Menampilkan aksara bali dari nama bangunan.

d. Menerapkan bentuk peciren bebadungan sebagai karakter arsitektur Denpasar.

Pada signage interior bangunan komersial, terdapat beberapa kriteria diantaranya:

a. Menggunakan material terbaru yang fungsional dan efisien.

b. Warna dominan menggunakan warna merah bata.

c. Tidak diharuskan, namun jika memungkinkan dapat digunakan aksara Bali

d.Menampilkan karakter peciren bebadungan pada frame (bingkai).

\subsection{Rancangan Desain Usulan Signage}

Berikut beberapa rancangan signage bangunan public di Kota Denpasar di antaranya:
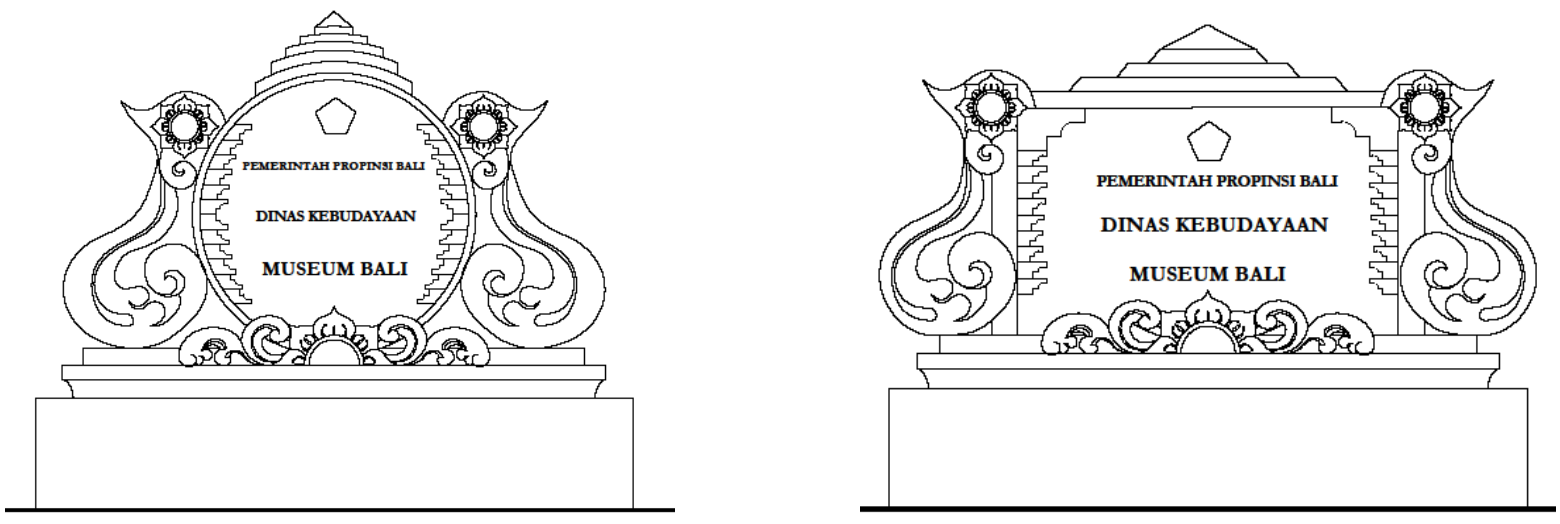

Gambar 4 dan 5. Alternatif 1 dan 2 Desain Usulan Eksterior Signage Sumber: Sketsa Penulis, 2020 
Desain ini mengedepankan bentuk peciren bebadungan pada bagian kepala, badan dan kaki signage. Pada bagian badan (bagian tengah) ditampilkan peciren bebadungan pada bagian tulisan. Material yang digunakan adalah bata merah. Latar tulisan berwarna hitam dari material granite. Tulisan difinishing dengan warna emas sehingga menonjol dan mudah terbaca oleh pengendara.

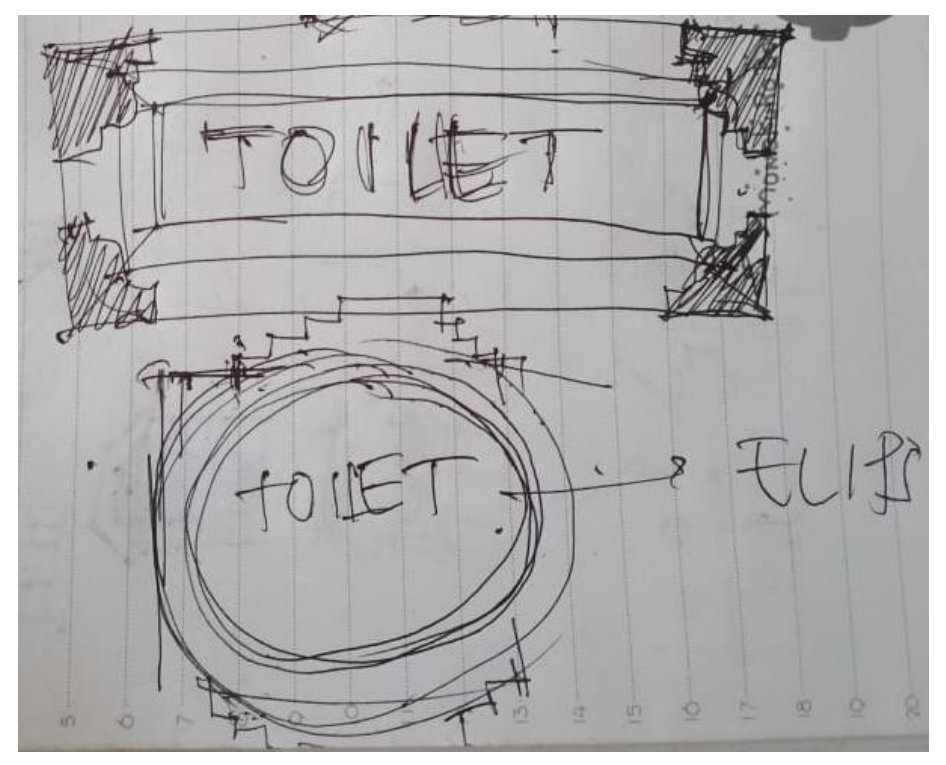

Gambar 5. Sketsa Interior Signage pada bangunan Publik di Kota Denpasar Sumber: Sketsa Penulis, 2020

Desain ini menerapkan bentuk peciren bebadungan pada bagian luar signage. Material yang digunakan merupakan kombinasi dari bata merah dan kayu. Tulisan menggunakan warna gold sehingga mudah terlihat oleh pengunjung.

\section{Kesimpulan}

Dari hasil analisa diatas, penulis dapat menyimpulkan bahwa sistem petanda pada arsitektur dan interior ruang publik di Kota Denpasar belum mencirikan arsitektur Kota Denpasar. Untuk memperkuat karakter arsitektur Denpasar terdapat dua hal yang paling mendasar, pertama adalah penggunaan bentuk peciren bebadungan yakni bentuk pola susun maju mundur bata merah yang disusun sedemikian rupa sebagai bentuk khas Arsitektur Denpasar yang membedakannya dengan Kabupaten lainnya di Bali. Yang kedua adalah pengguaan aksara Bali sebagai identitas local Bali. Dua hal ini yang penulis utamakan dalam perancangan, sehingga tercipta signage yang kreatif dan berkearifan local. Dengan tetap memperhatikan kriteria dan prinsip signage umum, ditambah dengan penerapan dua kriteria ini, diharapkan ke depannya akan terwujud desain signage yang kreatif dan berkearifan local, untuk mendukung arsitektur dan interior yang beridentitas Denpasar.

\section{Referensi}

Agus Sachari. (2007). Budaya Visual Indonesia. Jakarta: Penerbit Erlangga.

Fitriyana. (2017). Pengembangan Bandung Kota Kreatif Melalui Kolaboratif Komunitas. From http://sappk.itb.ac.id. Access Date, 08/08/2019.

Gelebet, I Nyoman. (2002). Arsitektur Tradisional Daerah Bali. Denpasar: Badan Pengembangan Kebudayaan dan Pariwisata.

Geriya, I Wayan. (2008). Transformasi Kebudayaan Bali: Memasuki Abad XXI. Surabaya: Penerbit Paramita.

Gomudha, I Wayan, Ed.Ngakan Putu Suweca. (2008). Pustaka Arsitektur Bali: Jelajah Arsitektur

Hunian Tradisional Bali. Denpasar: Ikatan Arsitek Indonesia Daerah Bali.

Moleong. (1999). Metodologi Penelitian Kualitatif. Bandung: PT. Remaja Rosdakarya. 
Noorwatha. (2014). Peciren Bebadungan: Studi Identitas Arsitektur Langgam Denpasar. From Jurnal Segara Widya, From https://id.scribd.com. Access Date, 04/08/ 2019.

Rahardjo, Mauro Purnomo. (1989). Meaning In Balinese Traditional Architecture (tesis). University of Kansas.

Rahayu, Ni Nyoman Sri. (2018). Creative Signage For Commercial Building Identity In Disruptive Era, As A Strengthening Character Of Local Architecture In Denpasar Bali. From Proseding International Seminars, Cultural Studies Doctoral Programe, Universitas Udayana, Bali.

Salain, Putu Rumawan. (2003). Representasi Arsitektur Tradisional Bali. Denpasar: Universitas Udayana.

Yudantini dkk. (2017). Sejarah dan Perkembangan Kota Denpasar sebagai Kota Budaya. Dalam https://seminar.iplbi.or.id. Access Date, 05/08/2019. 